\title{
ERROR ANALYSIS OF STUDENTS IN GRADE VI OF BUMIREJO ELEMENTARY SCHOOL 1 IN COMPLETING FLOWCHART DEBIT STORY PROBLEMS
}

\section{Isni Ramadhantri, Andhi Achmad, Arvrian Sukoco, Kartika Crysti Suryandari}

Universitas Sebelas Maret

isniramadhantri32@yahoo.co.id

\section{Article History}

accepted 30/09/2018

approved 12/10/2018

published 30/10/2018

\section{Keywords}

Types of Students

Errors, Story Problems,

Flow Discharge

\begin{abstract}
Mathematics is very important for human life. Mathematics has been taught since elementary school. Even so mathematics remains a subject that is difficult for students to understand. One sub-material that is considered difficult is the story of flow discharge. With this, researchers are interested in conducting research that aims to find out the types of students' errors and the factors that cause errors in grade VI students of SD Negeri 1 Bumirejo in solving the flow discharge story. This research is a qualitative descriptive study with data collection techniques using questionnaires, interviews and test questions. The subjects of this study were 8 students taken from 33 students in grade VI randomly / Random Sampling. The results of our study indicate that there are 5 types of errors in students, namely (1) reading errors about the problem (2) errors in understanding the problem (3) problem transformation errors (4) process skill errors (5) answers writing errors. Factors that cause student error are students who do not understand the problem, students are less careful and careful in working on the problem and students do not understand some of the meaning of words in the math problem. Therefore we decided to conduct a research entitled "Error Analysis of Students in Grade VI of Bumirejo Elementary School 1 in Completing Flowchart Debit Story Problems".
\end{abstract}

Social, Humanities, and Education Studies (SHEs): Conference Series https://jurnal.uns.ac.id/shes

p-ISSN 2620-9284 e-ISSN 2620-9292 


\section{PENDAHULUAN}

Pada era globalisasi terdapat berbagai bidang dalam kehidupan, salah satunya adalah bidang pendidikan, khususnya pendidikan matematika. Pendidikan matematika sangat penting bagi kehidupan manusia. Semua masalah dalam kehidupan yang membutuhkan pemecahan dengan cermat dan teliti bertumpu pada matematika. Seperti yang dijelaskan oleh Hans Freudental "matematika merupakan aktivitas insani dan harus dikaitkan dengan realitas" (Amir, 2016:9). Dengan demikian matematika tidak terlepas dari kehidupan sehari - hari karena matematika adalah salah satu ilmu dasar yang digunakan secara luas.

Pada umumnya matematika memiliki fungsi untuk mengembangkan kemampuan menalar melalui kegiatan penyelidikan, eksplorasi dan eksperimen, sebagai alat pemecahan masalah melalui pola pikir dan model matematika serta sebagai alat komunikasi melalui simbol, tabel, grafik, diagram dalam menjelaskan gagasan. Tujuan pembelajaran matematika adalah melatih cara berfikir secara sistematis, logis, kritis, kreatif dan konsisten (Wahyudi : 2015). Namun sering kita jumpai banyak orang yang tidak menyukai matematika karena pembelajaran matematika dinilai sulit dan sukar dipahami padahal matematika sangat penting bagi kehidupan manusia.

Permasalahan dalam pembelajaran matematika sering kita temui, khususnya di sekolah dasar. Masalah atau kesulitan yang sering dihadapi yaitu ketidaksesuaian kemampuan siswa dengan cara guru dalam menyampaikan materi. Siswa belum memahami materi yang disampaikan oleh guru tetapi guru sudah melanjutkan ke materi berikutnya. Sehingga kebanyakan siswa mengalami kesulitan dan siswa menjadi tidak menyukai matematika. Kesulitan - kesulitan belajar yang dihadapi siswa dapat disebabkan oleh faktor internal yang berasal dari diri siswa dan faktor eksternal yang berasal dari luaran siswa. Kesulitan siswa ini memungkinkan terjadinya kesalahan dalam menyelesaikan soal pada materi tertentu. Satu diantara materi yang dianggap sulit oleh siswa adalah soal cerita dengan materi debit aliran.

Menurut Saepudin dkk (2009 : 30) Debit adalah volume air yang mengalir dari suatu saluran melalui suatu pipa dalam satuan tertentu. Jadi, debit adalah jumlah air yang dipindahkan didalam satuan waktu pada titik tertentu. Besarnya debit air yang mengalir dapat dihitung dengan rumus :

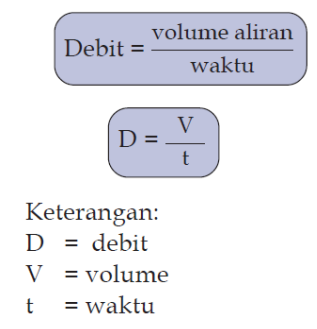

Pada materi ini sering di jumpai banyak siswa tidak menyelesaikan soal materi tersebut dengan baik. Maka dari itu peneliti ingin meneliti jenis - jenis dan faktor faktor kesalahan siswa dalam mengerjakan soal cerita materi debit aliran.

Dengan ini peneliti tertarik untuk melakukan analisis kesalahan siswa kelas VI SD Negeri 1 Bumirejo dalam menyelesaikan soal cerita materi debit aliran berdasarkan analisis kesalahan menurut Newman. Tahapan analisis Menurut Newman dalam Fatahillah dkk (2015:1) ada lima tahapan yaitu (1) kesalahan membaca soal (2) kesalahan memahami soal (3) kesalahan transformasi soal (4) kesalahan keterampilan proses (5) kesalahan penulisan jawaban akhir. Berdasarkan data yang diperoleh peneliti dari lapangan sebesar $84,84 \%$ siswa mengalami kesalahan dalam keterampilan proses yang meliputi kesalahan menghitung angka - angka dan kurang telitinya siswa dalam mengerjakan soal cerita tersebut. kesalahan pada tahap inilah yang sering dialami oleh siswa. 
Berdasarkan wawancara yang dilakukan peneliti dengan guru kelas VI dikatakan bahwa rata - rata siswa kelas VI masih kesulitan menghitung angka - angka desimal dalam menghitung debit aliran serta merubah satuan debit. Kemudian jika soal diaplikasikan dalam soal cerita, siswa masih bingung dalam memahami makna kata matematika pada soal. Kesalahan yang dilakukan siswa dibuktikan kebenarannya dengan melakukan tes identifikasi menghitung debit aliran. Tes tersebut dilaksanakan setelah siswa mengikuti materi volume dan debit aliran. Sebanyak 33 siswa mengikuti tes identifikasi tersebut

\section{METODE PENELITIAN}

Pada penelitian ini peneliti menggunakan pendekatan kualitatif. Pendekatan kualitatif adalah penelitian yang menafsirkan fenomena yang terjadi dan dilakukan dengan jalan melibatkan meode yang ada (Moleong : 2011) jenis penelitian yang digunakan adalah penelitian deskriptif karena penelitian deskriptif adalah penelitian yang menggunakan data berupa kata - kata.

Peneliti akan mendeskripsikan tentang kesalahan siswa dalam menyelesaikan soal cerita materi debit aliran. Teknik pengumpulan data merupakan cara yang digunakan peneliti untuk mendapatkan data dalam suatu penelitian. Teknik pengumpulan data yang digunakan pada penelitian ini yaitu observasi, tes tulis dan wawancara. Alat pengumpulan data yang digunakan dalam penelitian adalah tes soal cerita, pedoman wawancara dan lembar observasi. Subjek penelitian ini berjumlah 8 siswa yang diambil dari 33 siswa kelas VI di SD Negeri 1 Bumirejo. Penelitian ini dilaksanakan pada hari Sabtu tanggal 15 September 2018.

Dalam penelitian ini, sesuai dengan objek penelitian maka peneliti memilih observasi terstruktur. Observasi ini dilakukan dengan mengamati secara langsung proses pembelajaran matematika debit aliran dan saat siswa mengerjakan soal cerita materi tersebut. Dalam penelitian ini peneliti memilih wawancara semi-terstruktur yaitu wawancara dengan pertanyaan terbuka namun ada batasan tema dan alur pembicaraan, kecepatan wawancara dapat diprediksi, fleksibel tetapi terkontrol. Peneliti menggunakan pedoman wawancara yang dijadikan patokan dalam alur, urutan dan penggunaan kata. Peneltiti menggunakan teknik pengumpulan data tes tulis, tes ini berisi 5 soal cerita materi debit aliran.

Analisis data yang digunakan peneliti adalah melakukan observasi pada saat proses pembelajaran dan saat siswa mengerjakan soal untuk melihat bagaimana cara siswa menyelesaikan soal cerita, kemudian peneliti melakukan analisis persentase per deskripsi yang diperoleh sehingga dapat diperoleh data secara keseluruhan yang dihitung menggunakan rumus matematika dan diklasifikasikan dengan pernyataan. Kemudian disajikan dengan susunan yang sistematis.

\section{HASIL DAN PEMBAHASAN}

Penelitian ini dirancang untuk mendeskripsikan jenis - jenis kesalahan siswa dalam menyelesaikan soal cerita menurut Newman. Terdapat 5 aspek jenis kesalahan siswa dan dapat disimpulkan oleh peneliti indikator - indikator kesalahan siswa. Dapat di lihat di Tabel 1. Sedangkan persentase jenis - jenis kesalahan siswa dalam menyelesaikan soal cerita debit aliran yang di peroleh dari hasil penelitian terdapat pada Tabel 2.

Tabel 1 Indikator Jenis Jenis - Jenis Kesalahan Siswa

\begin{tabular}{lrl}
\hline No & Tipe Kesalahan & \multicolumn{1}{c}{ Indikator } \\
\hline $1 . \quad$ Kesalahan membaca soal & a. $\begin{array}{l}\text { Siswa tidak membaca soal dengan baik dan } \\
\text { benar }\end{array}$ \\
& b. $\begin{array}{l}\text { Siswa sulit mengartikan maksud kata dalam } \\
\text { soal }\end{array}$
\end{tabular}


2. Kesalahan memahami
soal

3. Kesalahan transformasi soal

\section{Kesalahan keterampilan proses}

5. Kesalahan penulisan jawaban akhir
a. Siswa tidak mampu memecahkan masalah pada soal
b. Siswa tidak dapat menentukan apa yang diketahui
c. Siswa tidak dapat menentukan apa yang ditanyakan
a. Siswa tidak dapat menuliskan maksud soal pada jawaban
b. Siswa salah menggunakan rumus
c. Siswa salah merubah satuan
a. Kesalahan menghitung
b. Siswa kurang teliti
a. Siswa menuliskan jawaban secara singkat
b. Siswa tidak menulis kesimpulan

Tabel 2. Persentase Jenis - Jenis Kesalahan siswa

\begin{tabular}{clc}
\hline No & \multicolumn{1}{c}{ Jenis Kesalahan Siswa } & Persentase (\%) \\
\hline 1. & Kesalahan membaca soal & $33.68 \%$ \\
2. & Kesalahan memahami soal & $36.83 \%$ \\
3. & Kesalahan transformasi soal & $49.96 \%$ \\
4. & Kesalahan keterampilan proses & $84.83 \%$ \\
5. & Kesalahan penulisan jawaban & $65.85 \%$ \\
\hline
\end{tabular}

Berdasarkan hasil analisis data menunjukkan bahwa jenis kesalahan yang dilakukan siswa kelas VI SD Negeri 1 Bumirejo dalam menyelesaikan soal cerita materi debit aliran berbeda - beda. Kesalahan yang sering dilakukan siswa dalam meneyelesaikan soal cerita adalah kesalahan keterampilan proses yaitu sebesar $84.83 \%$.

Pada tahapan jenis kesalahan membaca soal persentase kesalahannya adalah sebesar $33.68 \%$. Kesalahan ini meliputi siswa tidak membaca soal dengan baik dan siswa sulit mengartikan maksud kata dalam soal. Berdasarkan hasil wawancara dengan siswa, kesalahan dalam membaca satuan liter yang seharusnya setara dengan $\mathrm{dm}^{3}$ namun kebanyakan siswa mengartikan satuan liter sama dengan $\mathrm{m}^{3}$. Siswa juga kesulitan membaca angka - angka desimal yang tertulis didalam soal. Kategori kesalahan ini adalah kategori kesalahan paling rendah.

Tahapan kesalahan yang kedua yaitu kesalahan memahami soal dengan persentase $36.83 \%$. Kesalahan ini meliputi siswa tidak mampu memecahkan masalah pada soal, siswa tidak dapat menentukan apa yang di ketahui dan apa yang ditanyakan dengan tepat. Kebanyakan siswa tidak memahami soal cerita tersebut sehingga mereka tidak bisa menentukan apa yang diketahui dan apa yang ditanyakan dengan benar. Siswa tidak dapat memahami makna dari soal tersebut sehingga siswa tidak dapat menuliskannya kedalam kalimat matematika. Berdasarkan hasil wawancara yang menyebabkan siswa tidak dapat menuliskan apa yang diketahui dan apa yang ditanyakan dengan benar yaitu siswa bingung dengan kalimat soal cerita yang disajikan sehingga siswa hanya menuliskan angka - angka yang tertera didalam soal cerita. Siswa juga terlalu tergesa - gesa membaca soal sehingga salah menuliskan apa yang diketahui dan apa yang ditanyakan.

Tahapan kesalahan yang ketiga yaitu kesalahan transformasi soal dengan persentase sebesar $49.96 \%$. kesalahan transformasi soal ini meliputi siswa tidak dapat menuliskan maksud soal pada jawaban, siswa salah menggunakan rumus dan siswa salah merubah satuan. Berdasarkan wawancara dengan siswa, kesalahan ini disebabkan karena siswa tidak memahami maksud soal yang ditanyakan sehingga 
siswa bingung dengan langkah - langkah menyelesaikan soal cerita tersebut dan akhirnya siswa tidak dapat menuangkannya pada jawaban. Karena kebingungannya, siswa salah dalam mengaplikasikan rumus yang digunakan.

Tahapan kesalahan yang keempat yaitu kesalahan keterampilan proses dengan persentase sebesar $84.83 \%$. tahapan kesalahan ini merupakan tahapan kesalahan paling tinggi. Kesalahan ini meliputi kesalahan menghitung dan kurang telitinya siswa. Berdasarkan wawancara dengan siswa bahwa siswa kurang teliti dan kurang mahir dalam menghitung angka - angka soal khususnya perhitungan angka desimal. Siswa juga kurang teliti dalam perhitungan matematika yang harusnya merubah satuan terlebih dahulu namun siswa tidak merubahnya sehingga siswa banyak yang salah pada hasil akhir jawaban. Kesalahan menghitung juga dikarenakan siswa yang tergesa - gesa karena waktu mengerjakan soal yang terbatas.

Tahapan kesalahan yang kelima yaitu kesalahan penulisan jawaban akhir dengan persentase sebesar $65.85 \%$. Kesalahan ini meliputi penulisan jawaban secara singkat dan siswa tidak menulis kesimpulan pada jawaban akhir. Berdasarkan wawancara dengan siswa maksud dari siswa menuliskan jawaban singkat yaitu siswa hanya menuliskan jawaban langsung pada pengaplikasian kedalam rumus tanpa menuliskan langkah - langkah dalam penyelesaian soal cerita. Siswa juga tergesa gesa karena waktu yang terbatas dalam menyelesaikan soal cerita sehingga hanya menuliskan jawaban singkat dan siswa juga lupa tidak menuliskan kesimpulan pada jawaban akhir. Berikut ini sampel kesalahan siswa kelas VI SD N 1 Bumirejo dalam menyelesaikan soal cerita tentang debit air :

Tabel 3. Sampel kesalahan siswa kelas VI SD dalam menyelesaikan soal cerita tentang debit aliran.

\begin{tabular}{|c|c|c|c|c|}
\hline No & Nama Siswa & $\begin{array}{c}\text { Kesalahan } \\
\text { pada Soal } \\
\text { Nomor }\end{array}$ & $\begin{array}{c}\text { Jawaban } \\
\text { Siswa }\end{array}$ & Deskripsi \\
\hline 1 & Daneswara & 1 & $\begin{array}{l}\text { Diket : } \mathrm{v}=18 \\
\text { liter } \\
\text { w: } 1 \text { menit } \\
\text { Ditanyakan : } \\
\text { debit aliran } \\
\text { Jawab : V/w= } \\
18 / 60=3 \mathrm{l} / \mathrm{m} \\
=3000 \\
\text { Jadi debit air } \\
= \\
3000 \mathrm{~cm}^{3} / \text { detik }\end{array}$ & $\begin{array}{l}\text { Pada soal ditanyakan debit aliran } \\
\text { dengan satuan } \mathrm{cm}^{3} / \text { detik, } \\
\text { sedangkan pada jawaban siswa } \\
\text { dalam proses perhitungan siswa } \\
\text { tidak merubah satuan dari liter } \\
\text { menjadi } \mathrm{cm}^{3}, \text { maka dapat } \\
\text { disimpulkan bahwa siswa tidak } \\
\text { bisa dalam merubah satuan. }\end{array}$ \\
\hline 2 & Andika & 1 & $\begin{array}{l}\text { Diket : v awal } \\
=18 \text { liter } \\
\text { Waktu = } 1 \\
\text { menit = } 60 \\
\text { detik } \\
\text { Ditanyakan : } \\
\text { debit air } \\
\text { Jawab : V/D = } \\
3600 / 60=60 \\
\mathrm{~cm}^{3} / \text { detik } \\
\text { Jadi debit } \\
\text { bensin } 60 \\
\mathrm{~cm}^{3} / \text { detik }\end{array}$ & $\begin{array}{l}\text { Pada jawaban siswa tertulis } \\
\text { rumus yang salah dan juga } \\
\text { didalam memasukan data pada } \\
\text { rumus juga salah, maka dapat } \\
\text { disimpulkan bahwa siswa kurang } \\
\text { teliti dan salah menggunakan } \\
\text { rumus dalam mencari debit } \\
\text { aliran. }\end{array}$ \\
\hline
\end{tabular}


4

\section{$3 \quad$ Febriyanti}

Diket : debit 36 liter/detik

W : 1 jam

Ditanyakan volume Jawab : D $\mathrm{x}$ $\mathrm{W}=36 \mathrm{x}$ 3600 detik $=$ 119600 liter $=$ $119,6 \mathrm{~m}^{3}$

Jadi volume air yang dialirkan 119,6 $\mathrm{m}^{3}$

Diket : $\mathrm{D}=48$ $\mathrm{m}^{3} /$ detik

$\mathrm{W}=$ menit $=60$

detik

Ditanya volume Jawab : $V=D$ $\mathrm{x} W=48$ $\mathrm{m}^{3} /$ detik $\times 60$ detik $=2880$ $\mathrm{m}^{3}$

Jadi, air yang dipindahkan air terjun tersebut adalah 2880 $\mathrm{m}^{3}$

Diket : $\mathrm{D}=48$ $\mathrm{m}^{3} /$ det

$\mathrm{W}=1$ menit

Ditanya : V Jawab:

$D \times W=48$ $\mathrm{m}^{3} /$ det $\times 1$ menit $=48 \mathrm{~m}^{3}$ $=48000$ liter Jadi, volume air terjun adalah 48000 liter
Pada jawaban siswa $36 \times 3600=$ 119.600. Seharusnya jawaban yang benar adalah 129.600 liter sehingga apabila dijadikan satuan $\mathrm{m}^{3}$ menjadi $129,6 \mathrm{~m}^{3}$. Jadi dapat disimpulkan siswa kurang teliti dalam menghitung operasi perkalian. 
5 Arya M 2

4

6

Dafi

2

5

7 Sasmitha $\mathrm{H} \quad 2$
Diket : debit Pada lembar jawaban siswa, air terjun 48 siswa tidak lengkap menuliskan $\mathrm{m} 3 /$ det apa yang diketahui di soal, yang Ditanya : seharusnya diketahui waktu (W) berapa liter dan salah menggunakan rumus air yang $V=D / W$ yang seharusnya : $V=$ dipindahkan $\mathrm{D} \times \mathrm{W}$, sehingga dapat air terjun dimungkinkan bahwa siswa tidak dalam 1 menit dapat menentukan apa yang Jawab: diketahui dan salah 480/60det $=$ menggunakan rumus dalam 8 liter/menit menghitung volume debit air.

Jadi air terjun tersebut

dalam 1 menit

adalah 8

liter/menit.

Diket : Debit Pada lembar jawaban siswa 36 liter/detik siswa salah menuliskan yang Ditanya: ditanya yaitu Ditanya = waktu, Waktu yang seharusnya yang Jawab : D/W Ditanyakan = volume dalam $\mathrm{m}^{3}$. $=360$ Kemudian siswa salah liter/detik $=1$ menuliskan rumus $\mathrm{V}=\mathrm{D} / \mathrm{W}$ yang jam $=3600$ seharusnya $V=D \times W$. sehingga detik + 360 dimungkinkan siswa tidak detik = 3960 mampu memecahkan masalah liter/detik. pada soal, tidak dapat Jadi, air yang menentukan apa yang dialirkan ditanyakan serta salah dalam 1 jam menggunakan rumus.

adalah 3960 liter/detik.

Diket : $\mathrm{D}=48$ Pada lembar jawaban siswa $\mathrm{m} 3 /$ det menuliskan jawaban secara $\mathrm{W}=1$ menit = singkat dan tanpa menulis 60 detik kesimpulan, sehingga dapat Dit : volume disimpulkan siswa tidak mampu Jawab : 48 x menuliskan jawaban akhir yang $60=2880=$ lengkap .

2.880 .000

2 liter / detik Pada lembar jawaban, siswa menuliskan jawaban secara singkat saja. Dimungkinkan siswa terburu buru menuliskan jawaban, sehingga dapat disimpulkan bahwa siswa hanya menuliskan jawaban akhir secara singkat dan tanpa menggunakan langkah langkah terlebih dahulu

Dik: $\quad \mathrm{D}=$ Pada lembar jawaban siswa $48 \mathrm{~m}^{3} / \mathrm{det} \quad$ menuliskan $48 \mathrm{~m} 3 / \mathrm{det} \times 1=48=$ 


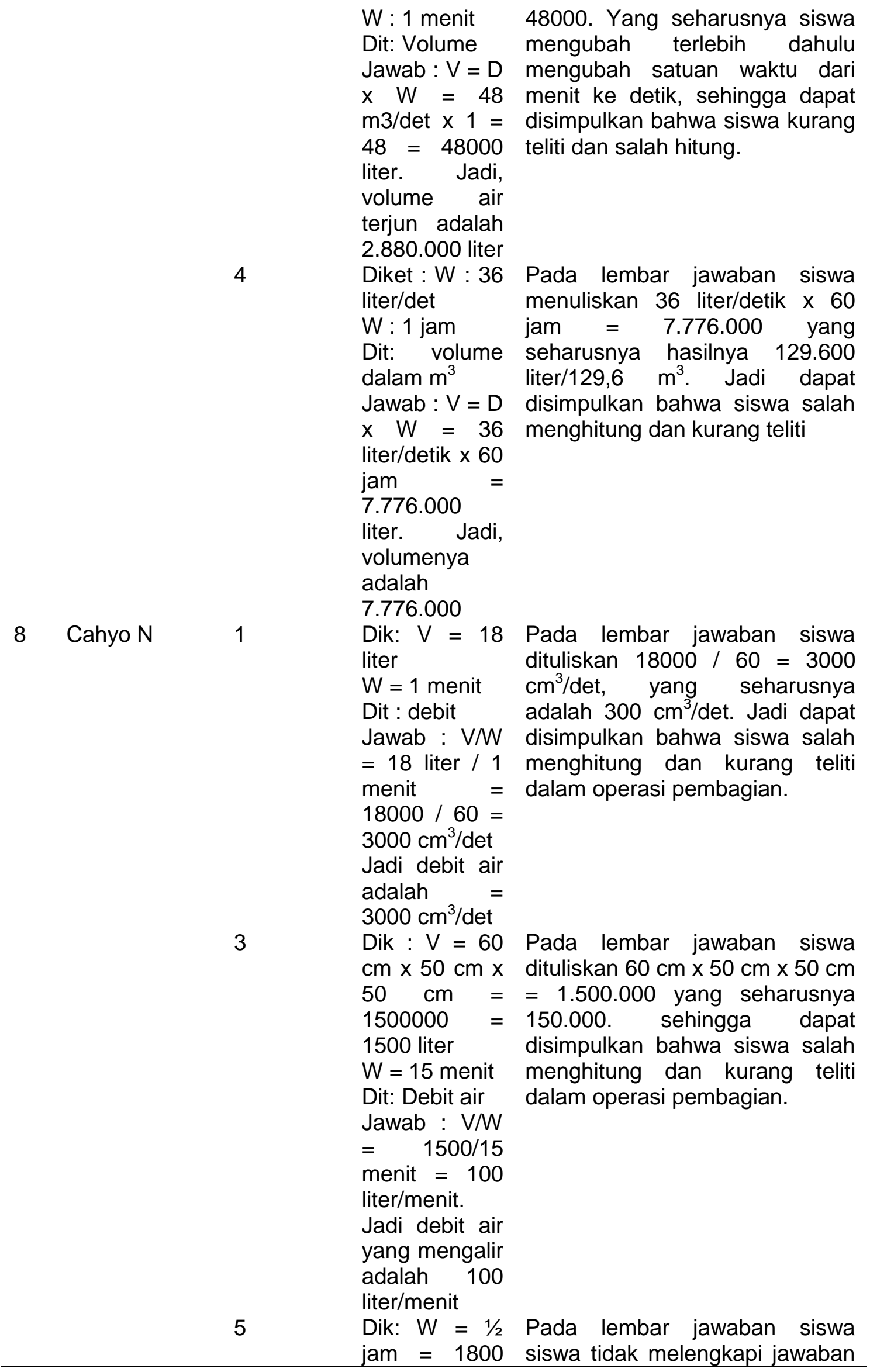




$\begin{array}{ll}\text { detik } & \text { akhir dengan kesimpulan, } \\ \mathrm{V}=3600 \text { liter } & \text { sehingga dapat diketahui bahwa } \\ \text { Dit: debit } & \begin{array}{l}\text { siswa kurang lengkap mengisi } \\ \text { dalam jawaban akhir dan kurang teliti }\end{array} \\ \text { liter/detik } & \\ \text { Jawab : } \mathrm{D}= & \\ \mathrm{V} / \mathrm{W}= & \\ 3600 \text { liter/1800 } & \\ \text { det =2 } & \end{array}$

Berdasarkan tabel sampel dari 8 siswa kelas VI SD N 1 Bumirejo dalam menyelesaikan soal cerita tentang debit air dapat dilihat bahwa kesalahan yang sering dilakukan oleh siswa kelas VI SD N 1 Bumirejo adalah kesalahan menghitung dan kurang teliti.

\section{SIMPULAN}

Berdasarkan hasil analisis data menunjukkan bahwa jenis kesalahan yang dilakukan siswa kelas VI SD Negeri 1 Bumirejo dalam menyelesaikan soal cerita materi debit aliran dapat diambil kesimpulan diantaranya:

1. Pada tahapan jenis kesalahan membaca soal persentase kesalahannya adalah sebesar $33.68 \%$. Kesalahan ini meliputi siswa tidak membaca soal dengan baik dan siswa sulit mengartikan maksud kata dalam soal.

2. Tahapan kesalahan yang kedua yaitu kesalahan memahami soal dengan persentase $36.83 \%$. Kesalahan ini meliputi siswa tidak mampu memecahkan masalah pada soal, siswa tidak dapat menentukan apa yang di ketahui dan apa yang ditanyakan dengan tepat.

3. Tahapan kesalahan yang ketiga yaitu kesalahan transformasi soal dengan persentase sebesar $49.96 \%$. kesalahan transformasi soal ini meliputi siswa tidak dapat menuliskan maksud soal pada jawaban, siswa salah menggunakan rumus dan siswa salah merubah satuan.

4. Tahapan kesalahan yang keempat yaitu kesalahan keterampilan proses dengan persentase sebesar $84.83 \%$. tahapan kesalahan ini merupakan tahapan kesalahan paling tinggi. Kesalahan ini meliputi kesalahan menghitung dan kurang telitinya siswa.

5. Tahapan kesalahan yang kelima yaitu kesalahan penulisan jawaban akhir dengan persentase sebesar $65.85 \%$. Kesalahan ini meliputi penulisan jawaban secara singkat dan siswa tidak menulis kesimpulan pada jawaban akhir.

\section{DAFTAR PUSTAKA}

Amir, Zubaidah. (2016). Psikologi pembelajaran matematika. Yogyakarta: Aswajapresindo.com

Fatahillah dkk. (2017). Analisis kesalahan siswa dalam menyelesaikan soal cerita matematika berdasarka tahapan Newman beserta bentuk scaffolding yang diberikan. Jember : Universitas Jember

Moelong. (2011). Metodologi Penelitian Kualitatif. Bandung : PT Remaja Rosdakarya

Pertiwi. (-). Analisis Kesalahan Siswa kelas IV SD dalam meyelesaikan soal bilangan pecahan senilai dan menyederhanakan bilangan pecahan. Sidoarjo : Universitas Muhammadiyah Sidoarjo

Saepudin dkk. (2009). Gemar Belajar Matematika untuk siswa SD/MI Kelas VI. Jakarta : Pusat Perbukuan Departemen Pendidikan Sundayana. (2015). Media dan Alat Peraga dalam Pembelajaran Matematika. Bandung : Alfabeta

Wahyudi. (2015). Panduan Pembelajaran Matematika Sekolah Dasar (Untuk Guru dan Calon Guru SD). Surakarta : UNS Press Nasional 